\title{
Empirical Analysis of Twins' Deficits in Bangladesh
}

\author{
Khandaker Jahangir Alam ${ }^{1}$, Bikash Chandra Ghosh², Md.Shafiul Islam³ , Md. \\ Elias Hossain ${ }^{4}$ \\ ${ }^{1}$ (Lecturer, Department of Economics, Begum Rokeya University, Rangpur, Bangladesh) \\ ${ }^{2}$ (Lecturer, Department of Economics, Pabna University of Science \& Technology, Pabna-6600, Bangladesh) \\ ${ }^{3}$ (Lecturer, Department of Economics, Begum Rokeya University, Rangpur, Bangladesh) \\ ${ }^{4}$ (Professor, Department of Economics, Rajshahi University, Rajshahi-6205, Bangladesh)
}

\begin{abstract}
Bangladesh represents a valuable case study for investing the dynamics of steadily high rates of budget and trade deficits. In this study an attempt has been made to empirically test the validity of Twin deficits hypothesis for Bangladesh using annual time series data from 1972-73 to 2011-12 fiscal year. Applying the VAR and Granger Causality after successfully running $A D F$ and PP unit root test and cointegration rank test this paper reveals that budget deficit Granger cause trade deficit and vice versa but the relationship does not stand for the long-run dynamics. In fact, the long run relationship depends on overall macroeconomics environment and performances of other relevant variables. Policy implication is that Government should reduce budget deficit to improve the trade account balance.
\end{abstract}

Keywords: Twin deficits; Bangladesh; Budget deficit; Trade deficit; Granger causality; VAR

\section{INTRODUCTION}

The fiscal decisions of the government are capable to affect household's consumption and saving behavior meaningfully as the fiscal policy has a key role to play in stabilizing the economy. According to the Keynesians, the households consider government bonds as net wealth. It implies that the substitution of debt by the government for taxes has a positive impact on private consumption and thereby on aggregate demand. The resulting decrease in total savings causes higher real interest rate, which in turn leads to crowd out private investment, capital inflows with exchange rate to appreciate and eventually leading to an increase in the current account deficit. The external deficit and budget deficit in the United States increased significantly during the 1980 's for several reasons. Many economists considered this co-movement of the twin deficits to be meaningful and concluded that a considerable share of the deterioration in the external balance was due to the emergence of record level budget deficits. This phenomenon of mutual connection was later on known as the twin deficits hypothesis.

Keeping in view the severity of the problem, it seems important to investigate the dynamics of steadily growing budget and trade deficits in Bangladesh as a case study. Bangladesh goes through on an average of 5\% deficit in budget, and an increasing trend of foreign trade deficit since 1971. Foreign trade deficit account scores highest $8 \%$ of GDP to lowest $2 \%$ of GDP for the last four decades, when budget deficit account fluctuates between minimum $3 \%$ to maximum $7.9 \%$. But in the recent years trade deficit is up-surging along with budget deficit mainly due to huge cost carried out to import petroleum products from the world market to meet up domestic demand of fuel for the power sector. The direction of influence between trade deficit and budget deficit is not apparently clear. This casts our attention to identify the direction or causality if any between these two macroeconomic phenomena.

The aim of the study is to examine empirically the conventional view that the budget deficit significantly affect trade account balance, that is, to find out if there exists any causal relationships between fiscal deficit and foreign trade deficit or not, if do so whether it is unidirectional or bidirectional or both.

The structure for the rest of the paper continues as follows: Section II provides the literature review for the studies that examined the twin deficit hypothesis. In section III, the theoretical grounds of the twin deficit hypothesis will be briefly discussed where as section IV represents the analytical framework of twin deficit. Section V gives data description and econometric methodology. Section VI discusses the estimation results while section VII is devoted to conclusion. The appendix and references are presented at the end.

\section{LITERATURE REVIEW}

There is an extensive theoretical and empirical literature that has examined the relationship between trade deficits and budget deficit and among other specified macroeconomic variables. Although there are so 
many studies in the literature on twin deficit hypothesis, there barely exists any consensus. We can simply classify them as studies supporting twin deficit hypothesis and studies concluding against twin deficit hypothesis. And most of them are headed toward two famous theoretical doctrines: The Keynesian Twin Deficit Doctrine and The Ricardian Equivalence Hypothesis (REH).

Historically, the so-called twin deficits hypothesis arose during the "Reagan fiscal experiment" in the 1980s, noticeable period of strong appreciation of the dollar with unusual shift hike in current account deficits. By and large, the existing studies on twin deficits phenomenon are mainly focused on the interrelationships and/or commoving relation in a bi-variate framework between budget deficits and trade balances (or Current account balances). Darrat (1988) shows the existence of bi- directional (Granger) causality between the government deficit and the trade balance during the period of floating exchange rates. According to Darrat this indicates that policy makers of U.S. may have responded with added government spending because of domestic hardships caused by the trade imbalance. Abell (1990) estimates a VAR system with several relevant explanatory variables. Using first - differenced data, Abell finds little support for the government deficit as a primary explanatory variable for the trade deficit measure. The results suggest the absence of the causal underpinnings of the twin deficits story. It is notable that the data sample - monthly observations from 1979 to 1985 - presents only a limited picture of the historical behavior of the two deficits and the associated variables. He finds that the budget deficit influences the trade deficit indirectly rather than directly. The main set of linkages involves causality from budget deficits to higher interest rate, foreign capital inflows, an appreciation of the exchange rate, and, lastly, to the trade deficits.

Islam (1998) analyzes twin deficit hypothesis in the context of Brazil for the period from 1973 to 1991. His result also supports the bi-directional relationship between budget and trade imbalances. Similarly in the case of Morocco, Mansouri (1998) using cointegration tests and error correction models states, that there is a bi-directional short and long run causality between fiscal and external deficits. In the case of Canadian economy, Normadin (1999) points out that there is a bi-directional causal relationship between the twin deficits. Ricardian Equivalence Hypothesis exhibits that change in the budget deficit will be fully offset by change in savings. That is, a reducing tax does not affect households' lifetime wealth because future taxes will go up to offset current tax decrease. So, current private saving rises when taxes fall (or accordingly budget deficit rises): households save the income received from the tax cut in order to pay for the future tax increase. So, a budget deficit would not cause a twin deficit. The empirical studies by Miller and Russek (1989), Dewald and Ulan (1990) and Kaufmann et al. (2002) also find supportive evidence on the Ricardian equivalence theorem, in which fiscal and external deficits are uncorrelated. Bhattacharya's (1997) empirical work employs a VAR model and sets out to examine the factors affecting the trade balance of the United States over the period 1976:i to 1995:iv. The main findings of his paper are: (i) the growth differential of the United States with respect to the rest of the world is not statistically significant in explaining the trade balance; (ii) neither the direct nor the indirect effect of the federal budget deficit on the trade deficit are statistically significant; and (iii) an appreciation of the real dollar leads to a deterioration of the trade balance in the medium term. Onafowora and Owoye (2006) applied cointegration technique for Nigeria and found evidence of a positive relationship between trade and budget deficits in both the short and long-run.

Although the present study does not include all thoughts and way of analyzing of the twin deficits problem but we can see that the topic is interesting and different results for different economies.

\section{THE ISSUE OF TWIN DEFICITS}

Both the external and the budget deficits in United States increased extensively during the 1980's. This co-movement led several researchers to reach the conclusion that this mutual relationship is recognized as the twin deficits hypothesis. The theoretical explanation for the said hypothesis based on the Mundell-Fleming open-economy model. According to this model (with the assumption of free capital mobility and under flexible exchange rate), an increase in the budget deficit puts an upward pressure on the rate of interest to attract foreign capital, which leads to an appreciation of the exchange rate and ultimately to a current account deficit. The Keynesian school of thought views the budget deficit to have a considerable impact on the current account deficit. According to the simple Keynesians approach, an increase in the budget deficit will increase domestic absorption by import expansion thereby, causing a current account deficit. Some researchers have examined the Keynesian proposition of twin deficits with reference to trade openness.

There is a significantly voluminous body of literature (e.g. Fleming, 1962; Mundell, 1963; Kearney \& Monadjemi, 1990; among others) which suggests that government budget deficits may cause trade deficits all the way through different channels. However, four hypotheses are important, which concern the twin deficits phenomenon.

The first hypothesis is based on the twin-deficit hypothesis. According to Keynesian view , a tax cut lowers national saving by rising private disposable income and hence private consumption (an increase in imports) causing a worsening of the current account deficit. 
The second channel is known as the Ricardian Equivalence Hypothesis (REH). According to this approach, this hypothesis holds the view that substitution of debt for taxes has no effect on aggregate demand or on interest rates for a particular expenditure path. This implies that the tax-financed expenditures do not affect private spending or national saving.

The third hypothesis claims a reverse causality running from current account to budget deficit. An increase in current account deficit put a pressure on government to expand more and these government expenditures leads to an increase in budget deficit.

The fourth hypothesis suggests a possibility of a two-way causality between the two deficits. In other words, a budget deficit causes current account to deteriorate and vice versa.

\section{ANALYTICAL FRAMEWORK OF TWIN DEFICITS}

According to the twin deficits notion, movements in the government deficit precede similar changes in the trade deficit, implying that past government deficits would explain a substantial portion of the movements in subsequent trade deficits.

To clarify the relationship between these two variables, it is helpful to begin with some national income accounting identities. First, individuals dispose of income (Y) either as consumption (C), saving (S), or taxes $(\mathrm{T})$;

$$
\mathrm{Y}=\mathrm{C}+\mathrm{S}+\mathrm{T}
$$

Second, income must arise from either the domestic scale of consumption goods (I), governmental goods (G), or the net scale of goods to foreign agents (Exports, $\mathrm{X}$, minus Imports, $\mathrm{M}$ )

Combining equations (1) and (2), we obtain

$$
\mathrm{Y}=\mathrm{C}+\mathrm{I}+\mathrm{G}+(\mathrm{X}-\mathrm{M})
$$

$$
\mathrm{C}+\mathrm{S}+\mathrm{T}=\mathrm{C}+\mathrm{I}+\mathrm{G}+(\mathrm{X}-\mathrm{M})
$$

The following national income accounting identity is useful for analyzing the relationship between budget deficits and trade deficits:

$$
\mathrm{T}-\mathrm{G}=(\mathrm{X}-\mathrm{M})+(\mathrm{I}-\mathrm{S})
$$

In words, equation (4) states that the government budget surplus is equal to trade surplus plus the excess of investment over private saving. Suppose then that the government fixes spending (G), and cuts taxes (T), thereby creating a deficits. Equation (4) indicates that, as a result, either the trade surplus (X-M) must decline or the excess of investment over saving (I-S) must decline, or both. Note that this conclusion follows directly from accounting and does not depend on any behavioral theories. Whether the impact of budget deficits falls on $(\mathrm{X}-\mathrm{M})$ or $(\mathrm{I}-\mathrm{S})$ is an open question. Economists trained in the traditional Keynesian theory have pointed to the budget deficits as the major cause of the trade deficits.

\subsection{Sources of Data}

\section{RESEARCH METHODOLY AND DATA}

Data collection is a challenging job in Bangladesh. Although monthly, quarterly and yearly data series are available for trade deficit but quarterly and monthly data series for the budget deficit are not available, we use annual data series for the period 1972-73 fiscal years to 2011-12 fiscal years for both variables. Budget deficit data series are taken from budget summery books from 1972 to 2012 for each year published by The Ministry of Finance of Bangladesh. There are two types of estimation of budget deficit .One including grant, other one is excluding it. We use the data series excluding grant because of insistence record of grant at several budget estimation. There are three types of trade deficit data series are being published by the Bangladesh Bank (BB), Bangladesh Bureau of Statistics (BBS) and Export Promotion Bureau (EPB). BB calculates trade deficit data on free on board (FOB) method, EPB estimates export data on FOB and import data on cost on freight (CIF) method. We use the BBS data set from its publication namely, Foreign Trade Statistics Book. Here it is mentionable that data set for the fiscal year 2011-12 is taken as projected and the rest are based on revised data for each year. And also mentionable that the above referenced data series books are stored in BB library, Dhaka. Both data series are taken in the form of Billions of Taka.

\subsection{Research Model}

In order to analyze the short-run dynamics and long-run relationships and to justify the causal link between trade deficit and budget deficit, we employ the following model:

$$
\boldsymbol{T D}=\boldsymbol{f}\left(\boldsymbol{B} \boldsymbol{D}_{\boldsymbol{t}}\right) \text {, ceteris paribus }
$$

The function can be presented in an econometric model as follows:

Where

$$
T D_{t}=\delta_{0}+\delta_{1} B D_{t}+u_{t}
$$

$\mathrm{TD}_{\mathrm{t}}=$ Trade deficit

$\delta_{0}$ is constant, $\delta_{1}$ is model coefficient and $u_{t}$, is the random error term. 
Based on the above equation we use unit root test, cointegration test, Granger causality test following Vector Auto-regressive Model (VAR) from U (VAR) = (TD, BD).

\subsection{Econometric Estimation Techniques}

This paper is mainly based on the Vector Auto Regressions (VAR), because independent variables are the lagged values of dependent variables. Time series econometric methods of both VAR and VEC Granger causality tests/block exogeneity tests were applied to find the causal relationship between trade deficit and budget deficit.

\subsection{Unit Root Test}

Literature has established that most time series variables are not stationary. Therefore, using nonstationary variables in the model might lead to spurious regression which cannot be used for precise prediction (Gujarati, 2003). Hence, our first step is to examine the characteristics of the time series data used for estimation of the model to determine whether the variables have unit roots, that is, whether it is stationary and the order of integration.

Time-series, say $T D_{t}$ and $B D_{t}$ are non-stationary in levels but stationary in first difference i.e. $T D_{t} \sim I(1)$ and $B D_{t} \sim I(1)$.

\subsection{ADF Test}

The purpose of the unit root test is to determine whether the series is consistent with I (1) process with a stochastic trend, or it is consistent I (0) process, that it is stationary, with a deterministic trend. Therefore we can write the standard ADF model for data set to estimate:

ADF model for unit root test can be written as:

$$
\begin{gathered}
\Delta T D_{t}=\delta_{0}+\delta_{1} T D_{t-1}+\sum_{i=1}^{n} \gamma_{1} \Delta T D_{t-1}+u_{t} \ldots \ldots \ldots \ldots \ldots \ldots(2) \\
\Delta T D_{t}=\delta_{0}+\delta_{1} \Delta T D_{t-1}+\sum_{i=1}^{n} \gamma_{1} \Delta T D_{t-1}+\partial_{t}+u_{t} \ldots \ldots \ldots \ldots \ldots(3) \ldots \ldots \ldots
\end{gathered}
$$

Where $\Delta T D_{t}=T D-T D_{t-1} i=1,2 \ldots \ldots n$. and $\delta_{0}, \delta_{1}, \partial$ are the parameters to be estimated and $\partial_{t}, u_{t}$ the white noise error.

\subsection{Phillips-Perron Test}

Dicky Fuller test assumes that the errors are statistically independent and have a constant variance. To remove that, Phillips and Perron (1988) developed a generalization of the dicky-Fuller procedure allowing fairly mild assumptions concerned the distribution of the errors. They incorporated corrections to the autocorrelated residuals. Phillips-Perron equations to be estimated are as follows:

$$
\begin{aligned}
\Delta T D_{t} & =\delta_{0}+(\delta-1) T D_{t-1}+\beta\left(t-\frac{T}{2}\right)+\sum_{i=1}^{\rho} \alpha_{i} \Delta T D_{t-1}+u_{t} \ldots \ldots \ldots \ldots \ldots \\
\Delta B D_{t} & =\delta_{0}+(\delta-1) B D_{t-1}+\beta\left(t-\frac{T}{2}\right)+\sum_{i=1}^{\rho} \alpha_{i} \Delta B D_{t-1}+u_{t} \ldots \ldots \ldots \ldots \ldots
\end{aligned}
$$

In both ADF and PP models the null hypothesis is the series contains a unit root or in other words it is assumed that the series is non stationary. If ADF or PP test statistic is higher than then critical values of Fuller table in difference significance level, we reject the null hypothesis and the alternative hypothesis of stationary will be established.

\subsection{The Cointegration Rank Test}

Once a unit root has been confirmed for a data series, the next step is to examine whether there exists a long- run equilibrium relationship among variables. The existence of long-run equilibrium (stationary) relationships among economic variables is referred to in the literature as cointegration which is very significant to avoid the risk of spurious regression. The basic idea behind cointegration is that if, in the long-run, two or more series move closely together, even though the series themselves are trended, the difference between them is constant. It is possible to regard these series as defining a long run equilibrium relationship, as the difference between them is stationary. A lack of cointegration suggests that such variables have no long-run relationship: in principal they can wander arbitrarily far away from each other (Dickey et. al., 1991). We employ the maximum likelihood test procedure established by Johansen and Juselius (1990) and Johansen (1991). Specifically, if TD is a vector of $n$ stochastic variables, then there exists a p-lag vector auto regression with Gaussian errors of the following form: Johansen's methodology takes its starting point in the vector auto regression (VAR) of order P.

$$
T D_{t}=\mu+\Delta_{1} T D_{t-1}+---------+\Delta \rho T D_{t-\rho}+\varepsilon_{t} \ldots \ldots \ldots \ldots(6)
$$


Where

$T D_{t}$ is an $n \times 1$ vector of variables that are integrated of order commonly denoted (1) and $\varepsilon_{t}$ is an $n \times 1$ vector of innovations.

The VAR can be rewritten as

$\Delta T D_{t}=\mu+\eta T D_{t-1}+\sum_{i-1}^{\rho-1} \Delta T D_{t-1}+\varepsilon_{t}$

Where,

$\Pi=\sum_{i-1}^{\rho} A_{i-1}$

and

$\tau_{i}=\sum_{j=i+1}^{p} A_{j}$

To determine the number of co-integration vectors, Johansen and Juselius (1990) suggested two statistic tests; the first one is the trace test. It tests the null hypothesis that the number of distinct cointegrating vector is less than or equal to $\mathrm{q}$ against a general unrestricted alternatives $\mathrm{q}=\mathrm{r}$. The test calculated as follows:

$$
\lambda \operatorname{trace}(r)=-T \sum_{i=r+1} \operatorname{In}\left(1-\hat{\lambda}_{t}\right)
$$

Where, $\mathrm{T}$ is the number of usable observations, and the $\hat{\lambda}_{t}$ are the estimated eigenvalue from the matrix. The Second statistical test is the maximum eigen value test $(\max )$ that is calculated according to the following formula:

$$
\lambda \max (r, r+1)=-T \operatorname{In}(1-\lambda r+1)
$$

The test concerns a test of null hypothesis that there is $r$ of co-integration vectors against the alternative that $r+1$ co-integrating vector.

\subsection{The Error Correction Model}

Once the cointegration is confirmed to exist between variables, then the third step requires the construction of error correction mechanism to model dynamic relationship. The purpose of the error correction model is to indicate the speed of adjustment from the short-run equilibrium to the long-run equilibrium state. The greater the co-efficient of the parameter, the higher the speed of adjustment of the model from the short-run to the long-run. For this model

$$
\begin{gathered}
\Delta T D_{t}=\delta_{1}+\delta_{2} \Delta B D_{t}-\rho \hat{v}_{i t-1}+v_{i t} \\
\Delta B D_{t}=\gamma_{1}+\gamma_{2} \Delta T D_{t}-\rho \hat{\varepsilon}_{i t-1}+\epsilon_{i t}
\end{gathered}
$$

\subsection{VAR and Granger-Causality}

In this paper, the convention of traditional and recent developments in regards to the use of causality test was followed. In the case of stationary and non cointegrated data set, standard Granger causality tests (VAR and Pair-wise) and in the case of stationary/ non-stationary and cointegrated data set VECM Granger non causality/block exogeneity tests were employed to find causality. Econometrics software STATA has been used to process data. Granger causality tests are conducted to determine whether the current and lagged values of one variable affect another. One implication of Granger representation theorem is that if two variables, say $\mathrm{TD}$, and $\mathrm{BD}$ are co-integrated and each is individually $1(1)$, then either TD must Granger-Cause or BD must Granger-cause TD.

$$
\begin{aligned}
& T D_{t}=\delta_{0}+\delta_{1} \sum_{i=1}^{n} \delta_{i} \Delta T D_{t-1}+\delta_{2} \sum_{j=1}^{n} \delta_{j} \Delta B D_{t-1}+e_{1 t} \ldots \ldots \ldots \ldots \ldots \\
& B D_{t}=\gamma_{0}+\gamma_{1} \sum_{i=1}^{n} \gamma_{i} \Delta B D_{t-1}+\gamma_{2} \sum_{j=1}^{n} \gamma_{j} \Delta T D_{t-1}+e_{2 t} \ldots \ldots \ldots \ldots \ldots
\end{aligned}
$$

\subsection{Unit Root Test Result}

\section{EMPIRICAL ANALYSIS AND RESULTS}

To check the stationary and determine orders of integration, we use both augmented Dickey Fuller (ADF) and Phillips-Perron (PP) tests. From the table 1 we can see the result of the Unit Root Test analysis using ADF. The result shows that both the variable, TD and BD are non stationary at level including both the cases of intercept and intercept-trend. But Stationary at first difference level at all 1\%, 5\% and $10 \%$ level of significances. 
Table 1: ADF Test of Stationary

\begin{tabular}{|c|c|c|c|c|c|c|}
\hline Name of Test & \multicolumn{6}{|c|}{ Augmented Dickey-Fuller Test (ADF) } \\
\hline & \multirow{2}{*}{\multicolumn{2}{|c|}{ At Lag 1}} & \multicolumn{2}{|c|}{ At level } & \multicolumn{2}{|c|}{ At First difference } \\
\hline Variables & & & Intercept & $\begin{array}{c}\text { Intercept \& } \\
\text { trend }\end{array}$ & Intercept & $\begin{array}{c}\text { Intercept \& } \\
\text { trend }\end{array}$ \\
\hline \multirow[t]{4}{*}{ TD } & \multicolumn{2}{|c|}{ Test statistics } & 1.457 & -0.445 & -5.213 & -6.225 \\
\hline & \multirow{3}{*}{$\begin{array}{c}\text { Test critical } \\
\text { value }\end{array}$} & $1 \%$ & -3.662 & -4.260 & -4.260 & -4.270 \\
\hline & & $5 \%$ & -2.964 & -3.548 & -3.547 & -3.552 \\
\hline & & $10 \%$ & -2.614 & -3.209 & -3.205 & -3.211 \\
\hline \multirow[t]{4}{*}{$\mathrm{BD}$} & \multicolumn{2}{|c|}{ Test statistics } & 3.516 & 1.661 & -3.935 & -5.270 \\
\hline & \multirow{3}{*}{$\begin{array}{c}\text { Test critical } \\
\text { value }\end{array}$} & $1 \%$ & -3.662 & -4.260 & -4.260 & -4.270 \\
\hline & & $5 \%$ & -2.964 & -3.548 & -3.547 & -3.552 \\
\hline & & $10 \%$ & -2.614 & -3.209 & -3.205 & -3.211 \\
\hline
\end{tabular}

Table 2 contains the result of stationarity checking of the model variables by using Phillip-Perron (PP) test; also confirm that both variables are stationary only at first difference.

\subsection{Lag Selection}

Selection of appropriate lag is more important for cointegration test and of course for Granger causality test. In this paper, we have used AIC, FPE, SIC and HQ criteria to select appropriate lag length. Running with STATA we have chosen the lag length supported by majority of the criteria using Varsoc command at length four.

Table 2: PP Test of Stationary

\begin{tabular}{|c|c|c|c|c|c|c|}
\hline Name of Test & \multicolumn{6}{|c|}{ Phillips-Perron test (PP) } \\
\hline & \multirow{2}{*}{\multicolumn{2}{|c|}{ At Lag 1}} & \multicolumn{2}{|c|}{ At level } & \multicolumn{2}{|c|}{ At First difference } \\
\hline Variables & & & Intercept & $\begin{array}{l}\text { Intercept \& } \\
\text { trend }\end{array}$ & Intercept & $\begin{array}{c}\text { Intercept \& } \\
\text { trend }\end{array}$ \\
\hline \multirow[t]{4}{*}{ TD } & \multicolumn{2}{|c|}{ Test statistics } & -0.398 & -2.124 & -8.646 & -9.456 \\
\hline & \multirow{3}{*}{$\begin{array}{c}\text { Test critical } \\
\text { value }\end{array}$} & $1 \%$ & -3.645 & -4.251 & -3.662 & -4.260 \\
\hline & & $5 \%$ & -2.961 & -3.544 & -2.964 & -3.548 \\
\hline & & $10 \%$ & -2.613 & -3.206 & -2.614 & -3.209 \\
\hline \multirow[t]{4}{*}{$\mathrm{BD}$} & \multicolumn{2}{|c|}{ Test statistics } & 3.359 & 1.102 & -9.489 & -8.057 \\
\hline & \multirow{3}{*}{$\begin{array}{c}\text { Test critical } \\
\text { value }\end{array}$} & $1 \%$ & -3.645 & -4.251 & -3.662 & -4.260 \\
\hline & & $5 \%$ & -2.961 & -3.544 & -2.964 & -3.548 \\
\hline & & $10 \%$ & -2.613 & -3.206 & -2.614 & -3.209 \\
\hline
\end{tabular}

\subsection{Cointegration Rank Test}

After examining the stationarity of the variable at $\mathrm{I}(1)$ we are ready to check the rank of cointegration between the variables which shows the presence of long term relationship between TD and BD. Employing the Johansen and Juselius multivariate cointegration test following maximum eigen value statistics and trace statistics (Table 3 and 4). We find out that both the variables are cointegrated at one percent and five percent level of significance at rank one (1).

Table 3: Unrestricted Co-integration Rank Test (Trace)

\begin{tabular}{|c|c|c|c|c|}
\hline \multicolumn{5}{|c|}{ Unrestricted Co-integration Rank Test (Trace) } \\
\hline Hypothesized & \multirow[t]{2}{*}{ Eigen value } & \multirow[t]{2}{*}{ Trace Statistic } & 0.05 & 0.01 \\
\hline No. of CE(s) & & & Critical value & Critical value \\
\hline None* & 0.65547 & 40.6955 & 15.41 & 20.04 \\
\hline At most 1 & 0.06279 & 2.3345 & 3.76 & 6.65 \\
\hline \multicolumn{5}{|c|}{$\begin{array}{l}\text { Trace statistics is significant at no rank implying that the null hypothesis of no rank is rejected. At rank } 1 \text {, the } \\
\text { null hypothesis of "not rank } 1 \text { " is rejected verifying } 1 \text { rank. }\end{array}$} \\
\hline \multicolumn{5}{|c|}{ Table 4: Unrestricted Co-integration Rank Test (Maximum Eigenvalue) } \\
\hline \multicolumn{5}{|c|}{ Unrestricted Co-integration Rank Test (Maximum Eigenvalue) } \\
\hline Hypothesized & \multirow[t]{2}{*}{ Eigen value } & \multirow[t]{2}{*}{ Max Eigen Statistic } & 0.05 & 0.01 \\
\hline No. of CE(s) & & & Critical value & Critical value \\
\hline None* & 0.65547 & 38.3610 & 14.07 & 18.63 \\
\hline At most 1 & 0.06279 & 2.3345 & 3.76 & 6.65 \\
\hline
\end{tabular}


the null hypothesis of "not rank 1" is rejected verifying 1 rank.

\subsection{Error Correction Result (ECM)}

Since we found that variables, TD and BD, are cointegrated at rank 1, so we need to check the dynamic stability and short term error correction. Using VARSOC command of STATA we select the appropriate lag length is four to run error correction model. Although the error correction coefficient contains negative sign and significant at two percent level but it is greater than absolute value 1. So, it shows unambiguous evidence of short term error correction. Except for BD at lag 2 and 3, none of the correction shows significant result (table $5)$.

Table 5: The Vector Error Correction Model Result at Lag 4

\begin{tabular}{|c|c|c|}
\hline & \multicolumn{2}{|c|}{ Vector Error Correction Results } \\
\hline Lag & DTD & DBD \\
\hline DTD(-1) & $0.1697279(0.814)$ & $-1.89938(0.106)$ \\
\hline DTD(-2) & $0.1648724(0.751)$ & $-1.243122(0.149)$ \\
\hline DTD(-3) & $0.1492667(0.707)$ & $-0.040579(0.944)$ \\
\hline DBD(-1) & $-0.8573054(0.038)$ & $-0.3971374(0.555)$ \\
\hline DBD(-2) & $-0.864899(0.004)$ & $-0.3300354(0.504)$ \\
\hline DBD(-3) & $-0.5229908(0.022)$ & $-0.1813312(0.583)$ \\
\hline Constant & $-1.931022(0.822)$ & $-5.056376(0.303)$ \\
\hline ECM(-1) & $-2.014264(0.019)$ & $0.7692442(0.118)$ \\
\hline R-square & 0.8299 & 0.8199 \\
\hline Chi-statistics & 131.7686 & 122.889 \\
\hline Chi-Statistics (prob.) & 0.0000 & 0.0000 \\
\hline RMSE & 50.2374 & 28.7981 \\
\hline
\end{tabular}

$\mathrm{P}$ value ()

\subsection{VAR and Granger Causality}

Applying Granger Causality test using up to four lag periods as selected using VARSOC in STATA, we examine the research hypotheses. After running VAR in STATA we test the Ganger Causality between trade deficit and budget deficit. The result shows that Chi-square statistics is significant for both hypotheses implying that the null hypotheses of (1) budget deficit does not Ganger cause trade deficit and (2) trade deficit does not Ganger cause budget deficit are rejected (table 6). From this findings we can also intuitively the null hypothesis (4) budget deficit and trade deficit are not independent and reject the null hypothesis (3) causality does not run in both directions. It also verifies the existence short run relationship between trade deficit and budget deficit.

Table 6: Result of Granger Causality Test Granger Causality Wald Test

\begin{tabular}{|l|}
\hline Null Hypothesis \\
\hline BD does not Granger cause TD \\
\hline TD does not Granger Cause BD \\
\hline
\end{tabular}
Observation

\begin{tabular}{|c|c|c|c|}
\hline 36 & Chi2-statistic & df & Probability \\
\hline 36 & 18.55 & 4 & 0.00 \\
\hline
\end{tabular}

TD does not Granger Cause BD

\section{CONCLUSION}

To sum up at last, the above analysis explores the casual relationship between budget deficit and trade deficit from the period 1972-73 to 2011-12 fiscal years. Although the study exposes the short run bidirectional causality between budget deficit and trade deficit, it does not establish any long run dynamic relationship between these two variables. The evidence that is obtained through causality testing justifies the view that fiscal deficits significantly contribute to a deterioration of the trade balance. Therefore, it can be recommended to the fiscal authorities to reconsider existing budget framework to achieve trade balance at least for the short term. And the appearance of huge fluctuations and high trend of deficits of both the variables for last five years, specially the high trends of budget deficit which remarks one-third of the total budget delivered great burden to the macro economy of Bangladesh. Because of the existence of many macroeconomic channels through which budget deficit influences trade deficit and vice versa, and none of these channel variables have been included in the model, it calls for reexamining the twin hypothesis involving them. It is also mentionable that due to trade liberisation on 1990 decade and inception of flexible exchange rate regime in June 2003 created two structural breaks in the economy which are not considered in the present study and it may opens broad scope of further research.

\section{REFERENCES}

[1] Darrat, A.F. Have Large Budget Deficits Caused Rising Trade Deficits? Southern Economic Journal, 54(4), $1998,879-87$.

[2] Abell, J.D. Twin Deficits during the 1980s: An Empirical Investigation, Journal of Macroeconomics, 12, 1990 , 81- 96.

[3] Islam, M.F. Brazil's Twin Deficits: An Empirical Examination, Atlantic Economic Journal, 26(2), 1998, $121-128$. 
[4] Mansouri, B. Fiscal deficits, Public Absorption and External Imbalances: An Empirical Examination of the Moroccan case, Economic Research Forum (ERF), Working Paper No. 0138, 1998.

[5] Normadin, M. Budget Deficit Persistence and The Twin Deficits Hypothesis, Working Paper No. 1994 (31), Centre for Research on Economic Fluctuations and Employment, Universite du Quebec, Montrel, 1994.

[6] Miller, S.M., Russek, F. S. Are the Twin Deficits Really Related? Contemporary, Economic Policy, 7, 1989, 91-115.

[7] Dewald, William G., and Michael Ulan. 1990. Twin-Deficit Illusion. Cato Journal 9, no. 3 (winter), 1990, $689-707$.

[8] Kaufmann, S., Scharler, J., Winckler, G. The Austrian Current Account: Driven by Twin Deficits or by Intertemporal Expenditure Allocation? Empirical Economics 27, 2002, 529-42.

[9] Bhattacharya R. The Trade Balance and the Real Exchange Rate: Evidence from a VAR for the United States. The Journal of Economics, XXIII. No. I, 1997.

[10] Onafowora, O.A., Owoye, O. 2006. An Empirical Investigation of Budget and Trade Deficits: The Case of Nigeria, The Journal of Developing Areas, 39(2), 2006, 153-174.

[11] Chowdhary, K. and Saleh, A.S. Testing the Keynesian Proposition of Twin Deficits in the Presence of Trade Liberalization: Evidence from Sri Lanka, Economics Working Papers, 2007.

[12] Fleming, J.M. Domestic Financial Policies Under Fixed and Under Floating Exchange Rates, International Monetary Fund Staff Papers, No. 10, 1962, 369-380.

[13] Mundell, R. Capital Mobility and Stabilization Policy Under Fixed and Flexible Exchange Rates, Canadian Journal of Economics and Political Science, 29, 1963, 475-85.

[14] Kearney, C., Monadjemi, M. Fiscal Policy and Current Account Performance: International Evidence on the Twin Deficits, Journal of Macroeconomics, 12, 1990, 197-220.

[15] Acaravci, A. and Ilhan, O. 2008. Twin Deficits Phenomenon: Empirical Evidence from the ARDL Bound Test Approach for Turkey, Bulletin of Statistics \& Economics, 2008.

[16] Ministry of Finance (MoF). Bangladesh Economic Review (1991, 2004, 2008, 2011), Dhaka: Ministry of Finance (MoF), Government of Bangladesh (GoB).

[17] Gujarati, D. N. Basic Econometrics. ( New York: McGraw Hill Inc, 2003). $4^{\text {th }}$ Edition

[18] Phillips, P.C.B., Peron, P. Testing for a Unit Root in Time Series Regression, Biometrika, 75, 1988, $335-346$.

[19] Dickey, D.A., Jansen, D.W., Thornton, D.C. A Primer on Cointegration with An Application to Money and Income, Review Federal Reserve Bank of ST. Louis, 73, 1991.

[20] Johansen, S., Juselius, K. Maximum likelihood estimation and inference on cointegration: with applications to the demand for money. Oxford Bulletin of Economics and Statistics. Vol 52, 1990, 169-210.

[21] Johansen, S. 1991. Estimation and Hypothesis Testing of Cointegration Vectors in Gaussian Vector Autoregressive Models, Econometrica, 59, 1991, 1551-80. 